\title{
COMPILATION CONTEXTS OF MEDIEVAL AND EARLY MODERN BULGARIAN CHARMS
}

\author{
Svetlana Tsonkova
}

\begin{abstract}
The article deals with the medieval and early modern Bulgarian verbal charms and their textual contexts. More specifically, the focus is on the manuscripts in which these charms can be found. Both the charms and the manuscripts are discussed as cultural phenomena, which were part of complex cultural contexts, including processes like compilation, usage, adaptation and transmission. The article traces the organising principles of the miscellanies containing verbal magic, and also the actors and factors that influence these manuscripts and their content. Then, the article discusses the specifics and the role of variation and practicality, and the complex interrelation between the written and the oral. Finally, the article points out some specific patterns and relations between the apotropaic and curative functions of the charms, the processes of written and oral transmission, and the broader textual content of the manuscripts. The main goal of the paper is to urge a discussion on medieval and early modern Bulgarian verbal charms in the light of their immediate textual and broader cultural environment.
\end{abstract}

Keywords: apotropaic magic, canonical and non-canonical texts, cultural context, medieval manuscripts, verbal magic, written and oral transmission, written charms

\section{INTRODUCTION}

The medieval and early modern Bulgarian verbal magic is a complex and diverse cultural phenomenon. As a central element in this sphere, the medieval and early modern Bulgarian charms share this complex nature. These charms constitute the source material for my study. More precisely, I refer to the manuscripts dating from the 14th-15th centuries (Petkanova 1982: passim; Popkonstantinov \& Kronsteiner 1994: 39-40), which contain these charms. They all existed in a multifaceted and multileveled environment. The charms were part of various processes: composition, compilation, translation, transmission, usage, application, adaptation, intermingling, continuation, distortion and oblivion, to mention a few. Additionally, there is the supernatural sphere, the human sphere, the quotidian sphere, the practical sphere, the sphere of written and oral texts, etc. Therefore, we should speak not of one, but of many, multiple and various contexts, levels and processes. 
The examination of the dynamics and interconnections of these contexts, processes and surrounding milieus is of primary importance for the deep understanding of charms as cultural phenomena. However, as Lotte Tarkka aptly points out:

The main problem with the notion of context is that context is in itself not a homogenic and unproblematic background, a given reality: it too consists of different cultural processes, different discourses, a multitude of things happening simultaneously or sequentially. Furthermore, the textualization of the culture as a whole into ethnographic accounts and descriptions of multiple contexts blurs the boundary between text, context and what could be called a meta-text: the presentation of the whole in manuscripts and secondary literature. (Tarkka 1993: 178)

This is very much true of written verbal magic and its contexts. The surrounding milieus of charms are not only extremely complex, but also very elusive. As T.M. Smallwood points out about his Middle English textual examples: "It is often hard to 'place' a charm by its context..." (Smallwood 2004: 12). Here I would add that also it is often hard to 'place' a manuscript or amulet with charms by their context.

The extant medieval and early modern Bulgarian charms are relatively short texts, written in Old Church Slavonic language. Usually, they are to be found in Orthodox Christian religious books: priest's service books (sluzhebnitsi) and books of occasional prayers (trebnitsi). The charms can also be found in miscellanies (sbornitsi) and healing books (lekounitsi) (Petkanova 1982: 40-44). When approaching the manuscripts (and their content of verbal magic and charms) within a particular process and context (in this article, this is the context of compilation), we face certain specific questions, which I shall address here. ${ }^{1}$ My aim and attempt is to track the patterns of compilation that shaped these manuscripts.

The main obstacle to be kept in mind here is that we work with source material, which is more or less fragmentary. The fullness of the picture and the depth of the evidence, provided by the extant source materials, are debatable too. There can only be a hypothesis on what the actual medieval and early modern verbal magic situation was like as a whole. The answers to the specific questions about the compilation process depend primarily on these surviving sources, with all their potential and limitations. This is followed by the contextualisation and the scholarly interpretations of the data. Full and ultimate answers are not available or possible. However, it is possible and important to look at the sources from various perspectives and to explore both the evidences and the lacunae. 


\section{ORGANISATION OF COMPILATIONS}

What is the organising principle of the compilations examined here? Are they arranged according to the functions of the words of power, according to their form, or according to the procedures and the paraphernalia applied? In other words, why are certain prayers or charms gathered together in a written form?

As it was said above, Bulgarian charms are usually found in Eastern Orthodox Christian religious books. On the one hand, the general content of each of these books is united under certain religious purposes, as specialised literature for priests or devotional literature for lay people. On the other hand, this content is often diverse and varied.

The first example is Trebnik (book of occasional prayers, dated 17th century, $\mathrm{NBKM}^{2}$ No. 622) (Tsonev 1923: 132-138). The manuscript contains the Akathist hymn dedicated to the Mother of God; fifty-three prayers and charms that are to be read or uttered on various occasions: celebration of church feasts, birthgiving, baptism, marriage, confession, harvest, for curing different illnesses, when building and consecrating a new house, when making a new well, for purifying food vessels, for protection against different illnesses, for protection against the Devil; canonical and non-canonical formulae for exorcising the Devil; blessings for good health; commemorative lists of people. Among the prayers, we can see a number of charms, the most prominent of which are the twelve texts against the nezhit ${ }^{3}$, grouped together under the title "Prayers against the Cursed Nezhit". They are preceded by another charm for an ill person and are followed by a prayer for the blessing of a new well.

The content of Trebnik No. 622 is very diverse and at the same time very consistent. The charms are not in the margins, but completely integrated among other texts. The twelve charms against the nezhit constitute the most remarkable part of the book. Actually, they form a peculiar section, dedicated to a specific health problem. The section starts with the following charm:

Jesus came down from the Seventh heaven, from his home, met the nezhit and asked it: "Where are you going?" And the nezhit answered: "I am going into the human head, in order to bemuse the brain, to break the teeth and the jaws, to deafen the ears, to blind the eyes, to distort the mouth, to block up the nose, so there will be headache day and night." And Jesus said to the nezhit: "Go back into the forest and enter the deer's head and the ram's head, because they can bear everything and still survive. And stay there until the end of Heaven and Earth. And be afraid of the Lord, who is sitting on the cherubim throne, until He comes to judge the entire universe and you too, rabid nezhit, who are the source of every infirmity. 
I am conjuring you, nezhit! Go away from the God's servant [say the name] in the name of the Father, the Son and the Holy Ghost."

The other anti-nezhit texts follow similar narratives. The tenth charm represents a special case, because of its peculiar benevolent supernatural character:

The nezhit fell from the sky, the blind shepherds saw it. They chased it without feet, caught it without hands, tied it without a rope, burned it without fire, killed it without a knife, and ate it without mouths. From the bones, the nezhit went into the flesh, into the skin, into the hair, and melted, like salt in water. Let it disappear in the same way from the God's servant [say the name] now, and forever and always.

And finally, the twelfth text against the nezhit played the role of an apotropaic amulet (Popkonstantinov \& Konstantinova 1988):

Adam had a nezhit and passed it on to Eve. Eve passed the nezhit to the lead, the lead passed it to the sea, the sea passed it to the sand, the sand passed it to the beach, the beach passed it to the grass, the grass passed it to the dew, and the dew passed it to the sun. The sun came up, and the nezhit perished in the God's servant [say the name] now, and forever and always.

Write this prayer on lead.

Trebnik No. 622 is a liturgical book, a practical manual for a clergyman and a collection of verbal magic. It contains canonical and non-canonical words of power, which cover the main events and issues in and of human life. The prayers and charms form a homogenous content. In my understanding, Trebnik No. 622 is an exemplary case for crisis management through verbal magic. The book is practically orientated, both as a priest's professional book and as a collection of words of power. The non-canonical texts are integrated among the canonical ones, forming a syncretic whole. Its purpose is the provision of effective verbal magical instruments for coping with everyday human problems.

The second example is Niketovo molitveniche (Niketa's book of prayers, dated 1787, NBKM No. 646) (Tsonev 1923: 161-166). This manuscript contains a drawing of a cross; prayers against fear, sword, arrows, bewitchment; a list of the names of Virgin Mary; a list of the names of the archangels; prayers and charms against illnesses, unclean powers, the Devil, the nezhit, storm and wind, thunder, lightning; prayers and charms for good luck at the court of law and when travelling; a list of the names of God; a charm for killing the enemy; five seals to be worn as amulets against nocturnal fear, wind and witchcraft, and for good luck in travelling and when going to a superior authority; part of the apocrypha Kamak padna. 
The content of Niketovo molitveniche is clearly apotropaic. The syncretic mixture of canonical and non-canonical is specifically focused on protection and aversion from evil. The Niketovo molitveniche is a special case, as it provides information about the owner (a certain Niketa). To some degree, the book can be seen as a personalised collection of verbal magic.

The third example is Sbornik (miscellany, dated 15th-16th centuries, NBKM No. 308) (Tsonev 1910: 252-254), whose content includes: orthography rules, recipes for ink, parts of the vitae of St. George and St. Alexis, prayers for birthgiving, divinatory texts (trepetnik, gramovnik, lunnik ${ }^{5}$ ), a charm against rabid dog bites, prayers for successful fishing, a charm for staunching blood, a charm against hard rain and against the nezhit to be written on lead. A note in the margin informs us that the book belonged (at least for some time) to a certain priest Michael.

The content of Sbornik No. 308 is truly miscellaneous and very practically and daily life-orientated. It shares features with the previous two examples, but it also shows some differences. Trebnik No. 622 is a liturgical book, containing some non-canonical texts. The Niketovo molitveniche is (most probably) a personal prayer-book, containing a mixture of canonical and non-canonical texts with emphasised apotropaic purpose. In comparison, Sbornik No. 308 is more like a manual with a variety of practical information. Still, it is in connection with the clerical milieu, as it is indicated by a note in the margin.

The forth example is Sborniche s apokrifni molitvi (collection of apocryhphal prayers, dated 17th century, NBKM No. 273) (Tsonev 1910: 174-175), which contains: drawings of three crosses, accompanied by the explanations of their apotropaic amuletic powers; a list of the 72 names of the Lord; lists of the names of the Mother of God, the archangels, John the Baptist and the apostles, all of them to be worn like amulets; the first chapters of the four gospels; fourteen strashni molitvi ${ }^{6}$ of Archangel Michael against plague, witchcraft, storm, and wind; of St. Peter and Paul against the Devil, plague, witchcraft, storm and wind; of St. Nicholas against evil wind and witchcraft; of St. Paul against evil; of St. George for good luck at war, when travelling and when going to the court of law; five prayers when appearing in front of the king or other superior; two charms against the sword and arrow; a prayer for saying before travelling; charms against thunder; against cramps and the nezhit; prayers and charms against plague, vampires, wolves' attacks on the cattle, beasts and bandits, and for protection of vineyards, fields and barns; twelve seals of king Solomon to be worn when going into battle, for the love of God, against magic, for the court of law, against plague, bewitchment, for travelling, against the arrow and sword, for successful trade, against storm and wind, against serious illnesses, against an evil encounter, against vampires and female malice. 
With its predominantly apotropaic content, the Sborniche s apokrifni molitvi is quite similar to the Niketovo molitveniche. Defence against evil and help in a variety of critical situations are the main topics in both manuscripts. However, the non-canonical charms and elements slightly predominate in the Sborniche $s$ apokrifni molitvi. The manuscript is actually written down in notebooks, with a very simple writing and arrangement of the text. It is possible that the book was written (or copied, or compiled) by someone for private usage (Tsonev 1910: 175).

Clearly, all these manuscripts focus on practical purposes. The texts inside feature benedictory and apotropaic functions: to bless, to sanctify, to purify, to expel the evil, to protect, and to cure. In my opinion, function is the main organising principle of the manuscripts. These books belong to religious literature, but they are also Fachliteratur. The content consists of texts and words of power, which have to accomplish certain functions, mainly benedictory, supplicatory and apotropaic ones. Prayers and charms and borderline cases ${ }^{7}$, the words and texts of power are gathered together in written form because of their effectiveness in providing supernatural help and support in an important or critical situation (Shniter 2001: passim). No matter whether the content is canonical or non-canonical, it is very difficult to separate the compilations from the functions of their content. In my understanding, the compilations exist because of these functions. These books contain, preserve and transmit the words and texts of power (canonical and non-canonical ones) as practical instruments for communicating with the supernatural.

The charms, the prayers, and the borderline cases are important instruments to cope with a crisis situation. Giving an example of a charm for curing a cow, Ulrika Wolf-Knuts points out:

The content of the charm was constructed in order to correspond to the needs of a certain situation in human life, and the components were taken from several spheres, culturally inherited as well as self-experienced. We must assume that charms were used in critical existentially important situations, in which the person who utilised the text referred to his or her own environment. (Wolf-Knuts 2009: 62-70)

A crisis could put the economic wellbeing and the physical existence of a rural household at a great risk. Therefore, the inhabitants have two choices: to give in, or to counteract the difficult situation. The use of charms means "to oppose the powers that cause the crisis and try to thwart them. Saying a charm would be one of several ways of coping with the dangerous situation". As "coping is a cultural, socially anchored, repetitive activity that opens a person's eyes to 
new opportunities in time of distress" (ibid.), the books with charms constitute a central element of this system of counteracting.

Therefore, the words and texts of power constitute an essential part of the crisis rites and crisis management in general. In the framework of verbal magic, the charms and prayers can be regarded as the last and the strongest defence against the disaster, illness or evil. They are the most powerful resort to cope with the critical situation; they are the culmination of all the efforts to influence and change reality. The contact with the Other World very often means a crisis. The interaction with the supernatural agents and forces is very often a battle, and very often an uneven one, especially in the case of health issues. The words of power provide the most effective possible techniques to direct this dialogue and to face such a crisis, and the strongest weapons to lead this battle. In their turn, the manuscripts and amulets appear as important manuals, preserving and providing the essential information and texts of verbal magic.

\section{DIVERSITY AND VARIATION OF CONTENT WITHIN COMPILATION}

The data from the sources show that the compilations tend to include a number of variations within a narrow range of themes. These themes are: health-related issues, protection against evil and against forces of nature, and provision of good luck and success. To the best of my knowledge, in general, the medieval and early modern Bulgarian verbal magic is predominantly apotropaic, focused on these three topics.

Within this general framework, the health-related verbal magic deals with the following issues: preservation of good health, prevention of health problems, protection against diseases, afflictions and injuries, and curative treatment and healing of illnesses, traumas, etc., such as snake bites, rabid dog or wolf bites, the nezhit, dental pains, haemorrhage, urine detention (in humans and horses), constipation, fever, cramps, spasms, swelling and festering of horse's legs, and prevention of a sudden death (especially by drowning). The preservation of health is closely connected with protection against various evil powers and agents. The list includes the Devil, various demons, personifications of different illnesses, evil and malevolent humans, and damaging forces of nature like winds, storms, heavy rain, hail, floods and fire. And finally, there is the theme of provision of good luck and success in different human activities. Here the list includes: appearance in the court of law, travelling, bee-keeping, fishing and wine-making. 
While the number of topics is rather limited, the texts dedicated to certain problems can vary significantly. The charms against the nezhit stand as the most prominent example. The twelve texts, gathered together in Trebnik (17th century, NBKM No. 622), demonstrate a variety of charm-types and constructive elements (encounter and narrative charms, conjuration and expulsion formulae, impossibilia and origin accounts, historiolae and ratifications) which represent twelve different variants for solving the problem (Conkova 2010: 101-118). Groups of charms against the nezhit can be found also in Sborniche s apokrifni molitvi (17th century, NBKM No. 273, containing four texts) (Tsonev 1910: 174-175) and Trebnik (1839, NBKM No. 1386, containing five texts) (Hristova \& Karadzhova \& Vutova 1996: 73-75). Other manuscripts and amulets contain single charms against the illness (Popkonstantinov \& Konstantinova 1988: 28-30). Thus, one single health problem is covered by a substantial number of texts.

The prayers and charms for protection against evil powers represent another example of variability within a narrow theme. Here the variation is expressed through different benevolent supernatural authorities, which help people and expel the evil. For example, the Sborniche s apokrifni molitvi provides such protection on behalf of Archangel Michael, Sts. Peter and Paul and St. Nicholas. Fevers, witches and the Devil are often expelled by St. Sisinnius. Some manuscripts, like, for example, the Niketovo molitveniche, put emphasis and hope in the amuletic power of the cross and the seals of king Solomon.

Another example of variation can be seen in the charms against snake-bites. Usually, they contain a long list of different names and epithets of the snake. While the historiola can vary significantly (Jatsimirskii 1913: 78-102) ${ }^{8}$, the list of names remains relatively unchanged and fixed. ${ }^{9}$ Thus, these charms have one of the longest and most elaborated expulsion formulae. In my opinion, the careful repetition and transmission of the complex charm structure (narrative combined with a list of names) proves the effectiveness attributed to this text.

In conclusion, the source material shows a repetition of limited themes and rich variation within each theme. If we accept that the extant source materials are representative enough, then the correlation between the small number of topics and the large number of variations could be an indication of the importance of these particular topics. It is remarkable how this particular set of themes and issues is repeated again and again in a number of manuscripts and amulets. The recurrent trio, health - protection against evil - good luck, is the basis for flourishing variation, especially among the non-canonical texts. The charms show a richness of forms and structures, while still treating the same circle of well-known problems time and again. 


\section{FACTORS AND ACTORS IN THE PROCESS OF COMPILATION}

The process of compilation is interconnected with other cultural processes. The phenomenon of compilation is inseparable from the whole big complex of traditions and practices, which apply and smooth the words of power (both charms and prayers). "Tradition is seen in relation to its user, an individual and a group, and to its arena, the physical environment which moulds cultural and socioeconomic activities." (Honko 2000: 17) Here the process of regularisation via erosion and sedimentation, when a charm becomes tradition-smoothed, is always active. In a flourishing tradition, there is no decay, only natural variation; "decay, growth and constancy all take place at the same time" (Roper 1997: 98). The normative and the remarkable are constantly and dynamically defined and re-defined, resulting in adaptations and variations of the existing charms. "An adaptation of tradition occurs only when it is used for special expressive purposes in specific living situations." (Honko 1981: 32) As Lauri Honko summarises, "flexibility rather than stability seems to be the key to the continuity of tradition, to the kind of 'invariability' typical of oral tradition which prevents variation from going astray and distorting the song or story completely" (Honko 2000: 4).

This dynamic process is also relevant to verbal magic and charms. The compilations with words of power reflect both the continuity and flexibility of the tradition. The compilations also play a role in the process of transmission. "There is no single model of charm transmission or charm performance suitable as a description for the entire genre." (Roper 1997: 98) The process and nature of the charm transmission do not have clear-cut borderlines. There can be a tight transmission, which is the passing of an oral text from one charmer to another without changes; a loose transmission, which allows deletions and innovations; a forgetful transmission, when sections of the text can be partially or completely lost or affected by cross-contamination by parts of other charms (Roper 1997: 18; Vlasova 1972: 26-30). The tight transmission, however, may include auditory substitution, mishearing, misreading and miscopying.

It is difficult to determine which type of transmission was at work in the Bulgarian examples. In my understanding, this is a case of loose transmission. When compared with historical parallels, the medieval and early modern Bulgarian texts show a number of innovations and an amalgamation of constructive elements from different charm-types.

Another important term here is text fixation, which is "a process by which a multiform oral text is 'fixed' by being written down in a single variant" (Roper 1997: 19). As concerns the Bulgarian medieval and early modern material, this situation is quite peculiar. Due to the fragmentation of the data, we do not know 
all the phases of the process of text fixation. Some of the extant medieval and early modern charms are single variants in the sense that they are the ones that survived. However, there are charms, variants of which can be found on amulets and in manuscripts, separated by several centuries. Judging from the extant sources, the medieval Bulgarian charms had their text fixation in two ways: on amulets (as verbal magic in action) and in manuscripts (as manuals for reference and transmission of verbal magical information). Of course, this is only a hypothetical statement, based on the surviving data.

The compilations with words of power are artefacts reflecting one aspect of a living tradition. Other aspects, however, remain elusive and obscure, and the question about the practitioners is one of them. Contemporary sources (for example sermons) contain some additional information on the charming tradition and practice. Quotations like the following shed some light on the figures of the practitioners:

And the priests have false writings in their Euchologia, like the bad Penitentials (Nomokanony) and the false Prayers for the Fevers. Heretics had distorted the traditions of the Holy Apostles, writing false words to deceive the vulgar; but the Council investigated them and cleansed them and cursed them. (Mathiesen 1995: 162)10

And:

And in their Euchologia, among the Divine Writ, the stupid village priests have false writings - sown by heretics for the destruction of ignorant priests and deacons - thick village manuscripts and bad Penitentials (Nomokanony) and the false healing Prayers for the Fevers and for infections and for sicknesses. And they write fever letters on prosphorae and on apples, because of sickness. All this is done by the ignorant, and they have it from their fathers and forefathers, and they perish in this folly. Heretics had distorted the traditions of the Church and the Canons of the Holy Apostles, writing false words. (ibid.: 162-163) ${ }^{11}$

Still, the data are far from complete, and the picture remains sketchy. It is uncertain who the practitioners and the users of the charms were, although some conjectures seem more probable than others. Valerie Flint writes that in the Early Middle Ages there were a large number of practitioners of magic, they were faceless and nameless, difficult to recover and to be described exactly, but "of an outstanding importance to our appreciation of the rise of magic" (Flint 1991: 59). It is difficult to apply this definition to the Bulgarian material and situation. Maybe there was such a host of practitioners of verbal magic, but we only know a few things about them. The role of the clergy appears to be 
central in the process of compilation of the manuscripts that contain charms. As William Francis Ryan points out, Christianity and practices like amulets, divination, pagan and quasi-Christian charms are late importations in Russia via Bulgaria and Serbia.

And it seems clear that the importers were for the most part the minor clergy, who until quite recently could be practitioners in magic and divination among the East and South Slavs, both Orthodox and Catholic, as they could in the West. (Ryan 2004: 121)

In Russia the Church, "despite its official attitudes, was certainly one route for the importation of particular kinds of charms: uncanonical prayers and practices in many cases from fairly early periods of Christianity in the late antique Mediterranean world, with apocryphal motifs and persons and intermixed with pagan elements" (ibid.). ${ }^{12}$ In the light of such transmission process, the quotations from On the True Books and the False are relevant. In my opinion, they can contribute to the understanding of the Bulgarian manuscripts and their contexts.

Although the reasons for such a situation are debatable, practicality is still the most probable explanation. Kazimir Popkonstantinov connects the introduction of the charms in Christian religious books with the daily life needs and practice of the local priests (Popkonstantinov 1996: 16-18). Maria Shniter shares a similar opinion (Shniter 2001: passim, esp. 40-50). And still, who used the words of power, especially the charms? Was it the village priests? It seems very probable that they were verbal magic practitioners, as many of the manuscripts with charms are liturgical books. What about the medieval and early modern Bulgarian folk healers? There are indications that such practitioners existed, yet the information about them is fragmentary and scarce (Angusheva \& Dimitrova 2002: 81-99; 2004: 273-290). This side of medieval and early modern verbal magic is still a difficult scholarly terrain.

What is the role of lay people in the making of compilations and addition of the marginal notes? In one case we know the person's name, in another case - the occupation. Niketa and his book of prayers are of special interest here. Niketa's name is mentioned many times throughout the whole manuscript of the Niketovo molitveniche. Most probably, he owned the manuscript, at least for some time. It is also highly probable that he used the words of power in practice. The charms seem to be too personalised. Although the book is a religious one, there are no direct indications whether Niketa was a priest or wrote the manuscript himself. Sbornik No. 308 was owned by priest Michael. Sborniche s apokrifni molitvi is de facto a notebook, most probably somebody's personal belonging, 
and as if compiled in order to provide fast reference to important apotropaic texts. Was it made and owned by another priest, whose name did not survive?

According to Honko, "while charms and rite formulae could be passed to the next generation of healers, an individually developed cognitive system could not. On the evidence of texts of charms and prayers, little can be deducted about a healer's personal beliefs and code of behaviour. It is, however, possible to identify in the texts the basic symbols of a healer's worldview. Many of these symbols will be much older than the environment in which the healer was active" (Honko 1993: 526). If this is to be related to the Bulgarian material, then we can see an interesting picture. The compilations with charms and prayers stand between the canonical and non-canonical, between the clerical and the lay, between the oral and the written. If we can identify a feature of the practitioner's view, this is the need for reliable and effective verbal magical instruments for communication with the supernatural and for protection against its menaces, as well as the tendency to preserve and transmit the words of power, regarded to be useful and efficient in coping with the quotidian issues, challenges and critical situations.

The interaction between the oral and the written shapes another cultural context. First of all, the clear-cut distinction between orality and literacy is unstable, "as there can be varying degrees of literacy in a community (total illiteracy, functional illiteracy, semi-literacy, occasional literacy, high literacy), and because 'texts' slip in an out of oral tradition, to print, to oral tradition again. Furthermore, many written texts can show signs of their traditional oral roots" (Roper 1997: 53). Charms are not only subjects of oral-written-oral-writtenetc. transmission; they are par excellence exemplary for such a transmission. The compilations with words of power give evidence "of the interplay of the oral and the written and, within each, of casual change and careful repetition" (Smallwood 2004: 13).

The notions of oral and written should not be regarded as polarities, connected in a binary opposition. Oral and written are only two of the many possible grades on the cultural scale.

Folklore studies have shown us time and again that oral traditions and texts co-exist in myriad ways. The 'Ethnopoetical' theory of registers developed by Dell Hymes and his colleagues discards the crudeness of the oral versus written dichotomy in favour of realistically complex explanation in terms of language and speech act. (qtd. in Roper 1997: 53)

On the one hand, verbal magic and charms are an oral discourse.

In the far wider reaches of society with no access to professional medical help, desperate recourse to charms would have been all the more likely, 
and all the more thoroughly oral. Given this unbounded non-literary circulation, when charms do turn up in writing we have every reason to expect corruption, incoherence, reworking and variation of all sorts. If we think of charms as texts, they are not so much textes mouvants as textes courants. (Smallwood 2004: 12)

This oral way is probably the oldest method for the transmission of words of power. Oral discourse goes back to very ancient times, beyond memory and written records. If widely represented, it is also connected to the difficulties in finding the original form or the oldest possible variant of a charm. Oral discourse and the oral way of transmission lead to the actual situation, in which "there was, then, no Ur-text that one could reasonably hope to recover, however many copies one might find" (ibid.).

On the other hand, charms are subject of written transmission, which is often accompanied by respect "for particular wording, for precise reiteration" (Smallwood 2004: 12-13). This written evidence and the written way of transmission are unique and of key importance. They should not be neglected or underestimated.

In fact one soon realizes that the written record, far from being universally set down from memory or dictation, is at some periods and in some types of document unlikely to be anything of the sort. Altogether, if we put together these different aspects of the transmission of charms, what we have to expect in studying them is evidence of the interplay of the oral and the written and, within each, of casual change and careful repetition. (Smallwood 2004: 13)

This quotation is repeated, because it aptly presents the most important point: the cultural contexts and processes (of compilation, adaptation, transmission, etc.) are a field of constant interaction and interplay, their core and essence. The medieval and early modern Bulgarian manuscripts with charms and prayers are textes courants per se, existing in a dynamic milieu. This environment can also be seen in relation to power. It is a matter of power to achieve a certain effect, power to communicate with the supernatural, power to protect from an illness or evil supernatural agent, power to oppose successfully a wide range of threats from both Our World and the Other World. Both the oral and written forms of the words of power are instruments in the service of the practitioner. The manuscripts with charms and prayers are practical manuals, providing the essential verbal magical information when needed. On the complex power relationship between the oral and the written, Owen Davies gives an example from early modern England, where "chapbooks were hardly the most impressive of literary formats, so continental cunning-folk also made written compilations 
of their contents in more awe-inspiring manuscript books" (Davies 2007: 176). There were two major cultural influences on the British cunning-folk: religion and literacy.

For cunning-folk the possession of literacy and literature were crucial, the inference being that when it came to assessing their worth, people placed more emphasis on the acquisition of written knowledge than other sources of magical inspiration. (ibid.: 183)

To sum up, the manuscripts with words of power "exist in two interactive domains, that of popular oral composition, in which a large number of stock elements can be arranged in a variety of traditional structures at the choice of the appellant or performer, and that of the written spell-book, in which the spell assumes a fixed form and may be transmitted, or collected, in this form" (Ryan 2004: 116). In the case of Bulgarian materials on amulets, the words of power written on an object create an amulet with all its powers. In the case of the charms in manuscripts, the written form is most probably meant to preserve important information, and also to be used as a reference and reminder device. It is also important where and how the charms are situated in the book and among other texts. As it was said above, they are often embedded or incorporated integrally in the content of the manuscript. It is difficult to determine if the charms were inserted or intruded in unexpected places.

However, there are cases when the charms seem to be added at a random place, in the margins or at the end of a book. These different categories "suggest different methods of transmission for the charm-copies concerned" (Smallwood 2004: 17). The oddly inserted and intruding charms could come from any source: from memory or from a written source (which in turn can be of various content, length, etc.). The integrated and "the 'embedded' charm-copies are of course straightforward examples of written transmission. In the British examples of T.M. Smallwood, the copies of charms found in the innumerable original 'receptaries' must again be examples of written transmission" (Smallwood 2004: 17). ${ }^{13}$

\section{PATTERNS}

From the above-said, several patterns can be outlined. Firstly, the process of compilation is closely connected with the functions of the texts in the manuscripts. The functional aspect is of primary importance in the shaping and existence of books with charms and prayers. The circle of themes is narrow 
(health protection against evil or good luck), but within each topic the charms show variation and diversity.

Secondly, the process of compilation is closely related to the transmission of the type oral-written-oral-written-etc. The written form inside the manuscripts is only one form of existence for the charms. As the data about medieval and early modern Bulgarian charming practices are fragmentary, a comparison with later folklore material can be very instructive.

Thirdly, as they contain predominantly apotropaic verbal magic, the compilations play an important role as instruments in crisis management. The manuscripts with words of power preserve and provide verbal magical tools, which help in solving urgent quotidian challenges and problems. Thus, the books and their content are also power instruments, used in power communication and power interaction between the human and the supernatural, between Our World and the Other World.

Fourthly, the process of compilation transforms the books as objects. The transformation can reach different depths. It can work by means of a simple addition of notes and marginalia. For example, manuscripts like Chasoslov s posledovaniia (Book of hours with the Daily Office, 1744, NBKM No. 1391) (Hristova \& Karadzhova \& Vutova 1996: 87-89) and Sluzhebnik s trebnik (Service book with a book of occasional prayers, 16th century, NBKM No. 257) (Tsonev 1910: 165-166) have otherwise canonical content, but their marginalia contain charms: in the first case this is a variant of the charm against the nezhit (Adam had a nezhit, gave it to Eve...); in the second case, these are charms to cure humans and horses. Or, the transformation can go deeper, like in most of the above-quoted manuscripts, in which the charms and borderline cases are included among the canonical prayers as organic parts of the book.

The above-written paragraphs illustrate how specific and yet interwoven and interrelated the different cultural contexts are. The notion of natural selection in folkloric terms is a good summary for this stage of the discussion:

Absence of performance arenas, invalidation of past mythologies, low memorability and other factors acting on a population of charms eliminates those examples less well adapted to their environment. The examples surviving to be passed on would tend to have characteristics with survival value to their offspring and in time the composition of the population would change in adaptation to a changing environment. The characteristics with survival value for verbal charms include memorability and perceived effectivity. (Roper 1997: 41)

More significantly, "charms can undergo transmissible changes in the period between initial reception and eventual transmission onward. Such changes 
may just be random mutation, but may also be deliberate on the part of the charmer, and the next recipient of the charm could transmit this deliberately altered form" (Roper 1997: 42). The medieval and early modern Bulgarian compilations containing words of power represent a completed stage in this natural selection, preserving charms with high survival value, namely, high effectivity. Thus, these manuscripts have an immense survival value in terms of verbal magic, crisis management and cultural history.

\section{NOTES}

1 These questions were raised, clarified and discussed in a series of personal talks with Richard Kieckhefer, to whom I am indebted for the inspiration and beneficial remarks.

2 Natsionalna biblioteka "Sveti Sveti Kiril i Metodii" (SS. Cyril and Methodius National Library).

${ }^{3}$ Personification of different health afflictions, especially migraine and tooth ache.

4 Translation by the author, made after the Old Church Slavonic text in Tsonev's edition.

5 Containing instructions for divination, based respectively on the twitches of the human body, thunder, and the phases of the moon.

6 'Horrific prayers' or 'terrible prayers'.

7 By borderline cases I mean the texts that have features of both charms and prayers. On the variety of such mixed forms, see Shniter 2001 and Roper 2005.

8 The historiola may include snake-bite accidents with Apostle Paul, Jesus Christ, Virgin Mary, or with ordinary people, happening in different combinations and settings.

9 For example, the list of the snake's names contains epithets like "venomous", "pernicious" and "harmful", and comparisons "snake like a cloud", "snake like a raven" and "snake with four mouths", most of which are translations from Byzantine sources.

${ }^{10}$ Quoting the Russian source O knigakh istinnykh i lozhnykh (On the True Books and the False) from the 12 th century.

${ }^{11}$ Quoted from a 14th-15th-century longer redaction of the same text.

${ }^{12}$ According to Ryan, the exorcistic charm of St. Sisinnius against the twelve fevers, the charm of St. Paul against snakebites and the charms against the nezhit are some of the examples of such transmission.

${ }^{13}$ Smallwood's argument is about English collections of charms, in which the number of charm copies and related prescriptions is too big and it is unbelievable that they were only derived from memory or from "an independent unwritten circulation". 


\section{REFERENCES}

Angusheva, Adelina \& Dimitrova, Margaret 2002. Drugite avtoriteti: slova protiv magosnitsi i baiachki v damaskinarskata traditsiia. [The Other Authorities: Sermons against Magicians and Charmers in the Tradition of the Damaskins.] Godishnik na Sofiiskiia Universitet Sv. Kliment Okhridski, Vol. 92. Sofia: Tsentar za slaviano-vizantiiski prouchvaniia Ivan Duichev, pp. 81-99.

Angusheva, Adelina \& Dimitrova, Margaret 2004. Medieval Slavonic Childbirth Prayers: Sources, Context and Functionality. Scripta \& e-scripta, Vol. 2, pp. 273-290.

Conkova, Szvetlana 2010. Megégni tüz nélkül. Betegségdémonok a késô középkori bolgár mágikus szövegekben. [Burnt without Fire: The Illness Demon in Late Medieval Bulgarian Magical Texts.] In: Éva Pócs (ed.) Mágikus és szakrális medicina. Budapest: Balassi, pp. 101-118.

Davies, Owen 2007. Popular Magic: Cunning-Folk in English History. London: Hambledon Continuum.

Flint, Valerie I.J. 1991. The Rise of Magic in Early Medieval Europe. Princeton, NJ: Princeton University Press.

Honko, Lauri 1981. Four Forms of Adaptation of Tradition. In: Lauri Honko \& Vilmos Voigt (ed.) Adaptation, Change, and Decline in Oral Literature. Helsinki: Suomalaisen Kirjallisuuden Seura, pp. 19-33.

Honko, Lauri 1993. Healing: Introduction. In: L. Honko \& S. Timonen \& M. Branch (eds.) The Great Bear: A Thematic Anthology of Oral Poetry in the Finno-Ugrian Languages. Helsinki: Suomalaisen Kirjallisuuden Seura, pp. 523-532.

Honko, Lauri 2000. Thick Corpus and Organic Variation: An Introduction. In: Lauri Honko (ed.) Thick Corpus, Organic Variation and Textuality in Oral Tradition. Helsinki: Suomalaisen Kirjallisuuden Seura, pp. 3-28.

Hristova \& Karadzhova \& Vutova 1996 = Khristova, Boriana \& Karadzhova, Darinka \& Vutova, Nina. Opis na slavianskite rakopisi v sofiiskata nrodna biblioteka, tom V. [List and Description of the Slavic Manuscripts in the National Library in Sofia, Vol. 5.] Sofia: Narodna biblioteka.

Jatsimirskii 1913 = Iatsimirskii, A. K istorii lozhnykh molitv v iuzhno-slavianskoi pis'mennosti. [On the History of Untrue Prayers in South Slavic Literature.] Izvestiia ORIaS, t. 18, kn. 3, pp. 1-102; Izvestiia ORIaS, t. 18, kn. 4, pp. 16-126.

Mathiesen, Robert 1995. Magic in Slavia Orthodoxa: The Written Tradition. In: Henry Maguire (ed.) Byzantine Magic. Washington, D.C.: Dumbarton Oaks, pp. 155177. Available at http://www.doaks.org/resources/publications/doaks-onlinepublications/byzantine-magic/magic08.pdf. last accessed on November 18, 2014.

Petkanova, Donka. 1982. Stara balgarska literatura v sedem toma. T. I. Apokrifi. [Old Bulgarian Literature in Seven Volumes. Vol. 1. Apocrypha.] Sofia: Balgarski pisatel. Available at http://www.promacedonia.org/bg_ap/index.html, last accessed on October 31, 2014.

Popkonstantinov, Kazimir 1996. Novootkriti epigrafski pametnitsi ot X-XI v. (apokrifni molitvi varhu olovo). [Recently Found Epigraphic Monuments from the Tenth-Eleventh Centuries: Apocryphal Prayers on Lead.] Trudove na II kongres po starobalgaristika. Sofia: Balgarska Akademiia na Naukite, pp. 15-19. 
Popkonstantinov, Kazimir \& Doncheva, Liudmila 1994. Apokrifna molitva ot X-XI v. varhu oloven amulet ot s. Odartsi, Tolbukhinsko. [Apocryphal Prayer from Tenth-Eleventh Century on a Lead Amulet from Odurtzi Village.] In: V. Velkov (ed.) Sbornik v chest na akad. Dimitar Angelov. Sofia: Balgarska Akademiia na Naukite, pp. 288-292.

Popkonstantinov, Kazimir \& Konstantinova, Velichka 1988. Za dva olovni amuleta s apokrifni molitvi X v. [About Two Lead Amulets with Apocryphal Prayers from the Tenth Century.] Paleoslavistika i epigrafika. V pamet na prof. Ivan Galabov. Sofia: Velikotarnovski Universitet Sv. Sv. Kiril i Metodii, pp. 28-31.

Popkonstantinov, Kazimir \& Kronsteiner, Otto 1994. Starob"lgarski nadpisi / Altbulgarische Inschriften. Die slavischen Sprachen, Vol. 36. Wien: Gelehrte Gesellschaft.

Roper, Jonathan 1997. Traditional Verbal Charms with Particular Reference to the Estonian and English Charm-traditions. MA thesis. Sheffield: University of Sheffield.

Roper, Jonathan 2005. English Verbal Charms. Folklore Fellows Communications No. 288. Helsinki: Academia Scientiarum Fennica.

Ryan, William Francis 2004. Eclecticism in the Russian Charm Tradition. In: Jonathan Roper (ed.) Charms and Charming in Europe. London: Palgrave Macmillan, pp. 113-127.

Shniter, Mariia 2001. Molitva i magiia. [Prayer and Magic.] Sofia: Univ. izd. Sv. Kliment Okhridski.

Smallwood, T.M. 2004. The Transmission of Charms in English, Medieval and Modern. In: Jonathan Roper (ed.) Charms and Charming in Europe. London: Palgrave Macmillan, pp. 11-31.

Tarkka, Lotte 1993. Intertextuality, Rhetorics, and the Interpretation of Oral Poetry: The Case of Archived Orality. In: Pertti J. Anttonen \& Reimund Kvideland (ed.) Nordic Frontiers: Recent Issues in the Study of Modern Traditional Culture in the Nordic Countries. Turku: Nordic Institute of Folklore, pp. 165-193.

Tsonev, Benio 1910. Opis na slavianskite rakopisi v sofiiskata nrodna biblioteka. Tom I. [List and Description of the Slavic Manuscripts in the National Library in Sofia. Vol. 1.] Sofia: Izdanie na narodnata biblioteka sv. Kiril i Metodii.

Tsonev, Benio 1923. Opis na slavianskite rakopisi v sofiiskata nrodna biblioteka. Tom II. [List and Description of the Slavic Manuscripts in the National Library in Sofia. Vol. 2.] Sofia: Izdanie na narodnata biblioteka sv. Kiril i Metodii.

Vlasova, Zoia 1972. K izucheniiu poetiki ustnykh zagovorov. [To the Study of the Poetics of Oral Verbal Charms.] In: C.N. Azbelev (ed.) Russkii fol'klor XIII: Russkaia narodnaia proza. [Russian Folklore XIII: Russian Folk Prose.] Leningrad: Nauka, pp. 194-201.

Wolf-Knuts, Ulrika 2009. Charms as a Means of Coping. In: Jonathan Roper (ed.) Charms, Charmers and Charming: International Research on Verbal Magic. Houndmills \& New York: Palgrave Macmillan, pp. 62-70. 